\title{
Extending the Shelf Life of Camembert Cheese via Controlling Over-Ripening by Bacteriocin of Newly Lactic Acid Bacterial Isolate LAB100
}

\author{
Manal Khider ${ }^{1}$, Khaled Elbanna ${ }^{2,3}$ \\ ${ }^{1}$ Department of Dairy Science, Faculty of Agriculture, Fayoum University, Fayoum, Egypt \\ ${ }^{2}$ Deptartment of Agricultural Microbiology, Faculty of Agriculture, Fayoum University, Fayoum, Egypt \\ ${ }^{3}$ Department of Biology, Faculty of Applied Science, Umm Al-Qura University, Makkah, Saudi Arabia \\ Email address: \\ mqa00@fayoum.edu.eg (M. Khider)
}

\section{To cite this article:}

Manal Khider, Khaled Elbanna. Extending the Shelf Life of Camembert Cheese via Controlling Over-Ripening by Bacteriocin of Newly Lactic Acid Bacterial Isolate LAB100. International Journal of Nutrition and Food Sciences. Vol. 6, No. 2, 2017, pp. 88-98. doi: 10.11648/j.ijnfs.20170602.15

Received: January 28, 2017; Accepted: February 13, 2017; Published: February 27, 2017

\begin{abstract}
Camembert cheese is a surface white mould ripened cheese; when full ripe the casein becomes liquefy as the intensive degradation occurs by proteinases from surface flora and results over-ripening and off flavor. To control this, partial purified bacteriocin like substances (PPBLS) from newly lactic acid bacterial isolate (LAB100) exhibited antifungal activity against Penicillium candidum (in vitro) were used. Inhibition (\%) of P. candidum by PPBLS at concentrations of 2, 4, 8, 16 and $32 \mathrm{mg} / \mathrm{ml}$ was $34,50,79,80$ and $85 \%$, respectively. Based on their superior antifungal potential activity; isolate LAB100 was phenotypically and genotypically characterized as newly Lactobacillus sp. For delaying the Camembert cheese over-ripening (in vivo), bacteriocin producing isolate LAB100 and its PPBLS were incorporated and applied in different camembert cheese treatments. Three treatments beside control were conducted; after brining all cheese treatments stored at $12 \pm 2^{\circ} \mathrm{C}$ to ripen for 12 days and then at $5 \pm 2{ }^{\circ} \mathrm{C}$ for more 30 days to complete ripening. Organoleptic properties, $\mathrm{pH}$ values and nitrogen distribution were determined during ripening period. In addition, the proteolysis of treated Camembert cheese was monitored by gel electrophoresis. The cheese treatment (T2) made with bacteriocin producer isolate LAB 100 added as co-culture to main starter recorded the highest total score, followed by T3 and the lowest one was recorded for control (T1). The highest WSN/TN\% was in T1; 5.4, 22.87, 34.41 and $57.65 \%$ at $3,10,20$, and 40 days after brining, respectively, while the lowest WSN/TN\% was recorded for treatment that made with both bacteriocin producer strain LAB100 and sprayed by PPBLS solution after 3 days of brining (T3), where it was $5.05,9.85,13.82$, and $31.74 \%$ at the same previous ages, respectively. These results were confirmed by gel electrophoresis, indicating that bacteriocin producer LAB100 and or its bacteriocin controlled the protein degradation. These results suggest that both bacteriocin producer strain and its PPBLS minimize the growth of $P$. candidum as a consequence the rate of proteolysis was controlled and hence extending the shelf life of Camembert cheese is occurred.
\end{abstract}

Keywords: Control Camembert Cheese Over-Ripening, Surface Mould Ripened Cheese, Proteolysis Control, Penicillium candidum, Bacteriocin Producing Lactic Acid Bacteria, Antifungal

\section{Introduction}

Cheese ripening is a time-consuming process; involving complex and well-balanced reactions between glycolysis, proteolysis and lipolysis of the milk components [1]. Proteolysis is a relevant biochemical transformation during the ripening of most cheese varieties. During ripening; $\alpha \mathrm{s}_{1}$, $\alpha \mathrm{s}_{2}, \beta$-and para $\mathrm{\kappa}$-casein is hydrolyzed to free amino acids by proteinases originate from a wide range of sources. The activity of these enzymes can be affected by alterations in cheese manufacture and storage conditions [1, 2]. The caseins are insoluble in many solvents, but peptides produced from them may be soluble and thus the proportion of soluble nitrogen will increase with proteolysis. The products of proteolysis vary in size from large peptides comparable to intact caseins (eg, $\alpha_{\mathrm{sI}}-\mathrm{CN}$ f 24-199, the primary product of 
chymosin action on $\alpha_{\mathrm{s}}$-casein) to free amino acids and certain peptides [3]. Camembert cheese is a surface mould ripened cheese which made from cows' milk; it is soft with a creamy interior and a white velvety rind due to the growth of the white mould namely Penicillium candidum [4] within ten days of ripening prior to packaging. From the date of packing the cheeses have a seven week shelf life; therefore methods to extend products shelf life without affecting its quality would increase the company's distribution capabilities [5]. The texture becomes soft and smooth only during ripening as a result of extensive proteolysis and an increase in $\mathrm{pH}$ [4]; the mould gives the cheese it's characterized of organoleptic properties by the end of ripening [6]. This type of cheese ripens very quickly because of the rapid growth of surface flora, and hence cannot be ripened for extended periods and must be marketed in a rather short time because it contains high moisture content which reduces the shelf life [7]. Camembert cheese considered being the most expensive imported soft cheese type available in the local market. Extended ripening results in a cheese with too much protein decomposition and this is brought about by the protease of $P$. candidum [4]. During ripening of surface mould-ripened cheese varieties the $\mathrm{pH}$ increases and that facilitates the release of sapid compounds during mastication. It contributes directly to flavour and to off-flavour (e.g. bitterness) of cheese through the formation of peptides and free amino acids $[8,9]$.

Methods for acceleration ripening of cheese, have been the primary focus of the world wide dairy industry, as the maturation of cheese is responsible for a portion of the total production cost [10]. However, the trials to slow and control maturation in order to improve shelf life of some cheeses is gaining significant commercial interest because of the potential to open and exploit new market opportunities, allowing for longer distribution chain and exportation; extending the shelf life of cheese requires the simultaneous investigation into both cheese and storage technologies [5, 11]. The studies about control ripening conditions was through using gases like $\mathrm{CO}_{2}$; which could potentially use to slow the development of off flavours and extend the shelf life of solid dairy foods $[12,13]$. Respiration rate of Penicillium camemberti was increased with $\mathrm{CO}_{2}$ partial pressure values ranging from 0.1 to $0.4 \mathrm{~Pa}$. Growth of Penicillium camemberti could also be limited by minimize the oxygen in ripening chamber by making partial pressure of the oxygen in the ripening chamber equal to zero; which stunted the growth of Penicillium camemberti $[12,14]$. Reducing water activity, relative humidity or regulating temperature during ripening is also increase shelf life [14]. Changing in temperature during storage of Camembert cheese can control its ripening; this was studied by Swan (2011) [5], who found that storing Camembert at $-2^{\circ} \mathrm{C}$ for up 6 weeks, followed by maturation at $+4^{\circ} \mathrm{C}$ for eight weeks was successfully controlled the rate of maturation.

Lactic Acid Bacteria (LAB) are unique bacterial group, which are granted "Generally Recognized As Safe (GRAS) that have been extensively used to improve both the flavor and texture of fermented foods, and provide protective mechanisms either as a probiotic or antimicrobial biopreservatives. The potential and ability of LAB to produce several interesting metabolites such as organic acids, enzymes, exopolysaccharides, probiotic properties and antimicrobial substances such bacteriocins have attracted the attention of many researcher in recent years $[15,16]$. Bacteriocins are a kind of ribosomal synthesized and extracellularly released antimicrobial peptides and become one of the weapons against microorganisms due to the specific characteristics of large diversity of structure and function, natural resource, and being stable to heat. Bacteriocins of LAB are considered as safe natural biopreservatives, as it could be degraded in gastrointestinal tract by the proteases. Many recent studies have purified and identified bacteriocins for application in food technology as biopreservative for extending the shelf-life of many food products [17-21]. However, no studies have specifically investigated the influence of bacteriocin or bacteriocin producing bacteria on the ripening of Camembert cheese.

This work aims to: (i) Control the over-ripening of Camembert cheese and extending its shelf life by bacteriocinproducing lactic acid bacteria and studying its effect on the growth of Penicillium candidum and the rate of proteolysis, organoleptic properties and consumer acceptability, (ii) Identify the most promising bacteriocin-producing strain based on phenotypic and 16s rRNA gene sequencing, (iii) Production and purification of bacteriocin and determination of the antifungal activity of partial bacteriocin against Penicillium candidum.

\section{Materials and Methods}

\subsection{Bacteriocin Producing Strain and Growth Media}

In this study, the isolate LAB 100 was selected among 120 lactic acid bacterial isolates was isolated from different fermented dairy products collected from local market using MRS medium [22] and screened for bacteriocin production using agar well diffusion technique. Penicillium candidium was grown on malt extract agar at $28^{\circ} \mathrm{C}$ for 7 days and stored at $4^{\circ} \mathrm{C}$.

\subsection{Phenotypic and Genotypic Characterization of Bacteriocin Producing Isolate (LAB100)}

The isolate LAB100 was morphologically characterized as described in Bergey's Manual of Determinative Bacteriology [23]. Colonies with a Lactobacilli-like morphology (white, smooth, convex) was isolated and purified and examined for general characters of Lactobacilli, Gram-positive, catalasenegative, non-motile, non-spore-forming rods, that able to coagulate milk and not able to produce indol or liquefying gelatin, were considered as Lactobacilli isolates. For further phenotypic characterization, identification by API $50 \mathrm{CHL}$ kit (Bio Mérieux, France) was conducted in accordance with manufacturer's instructions and the species level was preliminarily identified from the API database. 
Genotypic characterization of strain LAB100 was characterized based on the sequencing of $16 \mathrm{~s}$ rDNA gene. For this, genomic DNA from lactic acid bacterial strain was isolated according to the method described by Elbanna et al (2010) [24]. 16s rDNA fragments ( $\sim 1540$ bp) were sequenced using an ABI 3730xl automated DNA sequencer (Applied biosystems USA) through Lab Biotechnology Company, Egypt.

The phylogenetic reconstruction was done using the neighbour joining method [25] using Bacillus subtilis strain DSM 10 (gi|228716557|) and Lactococcus lactis strain 200703 (gb|KU899037) as out group.

\subsection{Production and Purification of Bacteriocin of Lactobacillus sp. LAB100}

Bacteriocin like substance (BLS) was produced from strain LAB 100 using low coast permeate medium. For this, three litter of diluted permeate medium ( 2 portion water: 1 portion permeate) containing $\mathrm{K}_{2} \mathrm{HPO}_{4}(2 \mathrm{~g})$, Sodium acetate $3 \mathrm{H}_{2} \mathrm{O}$ $(5 \mathrm{~g})$, Tri-ammonium citrate $(2 \mathrm{~g})$ and Tween $80(1 \mathrm{ml})$ was prepared, then $\mathrm{pH}$ was adjusted to 6.4 with $1 \mathrm{M} \mathrm{HCl}$ and autoclaved at $121^{\circ} \mathrm{C}$ for $20 \mathrm{~min}$. The medium was inoculated with $10 \%$ inoculum $\left(10^{7} \mathrm{CFU} / \mathrm{ml}\right)$ from fresh culture and anaerobically incubated at $37^{\circ} \mathrm{C}$ for $48 \mathrm{~h}$. After incubation period, cell free supernatants were obtained by centrifugation of the bacterial cultures at $5000 \times g$ for $30 \mathrm{~min}$. The crude extract was concentrated by rotary evaporator to $300 \mathrm{ml}$, and then purified by precipitation with $50 \%(\mathrm{w} / \mathrm{v})$ ammonium sulfate. The precipitated pellets containing bacteriocin was suspended in $150 \mathrm{ml}$ of phosphate buffer $(50 \mathrm{mM}, \mathrm{pH} 7.2)$ to obtain 20 fold concentrated bacteriocin. To eliminate the inhibitory effect of organic acids and salts, the concentrated BLS was dialyzed three times against the same buffer at $4{ }^{\circ} \mathrm{C}$ for $24 \mathrm{~h}$. To eliminate the inhibitory effect of hydrogen peroxide, BLS was treated with catalase $(1 \mathrm{mg} / \mathrm{ml})$. The final treated BLS was filtrated through miliporefilter $(0.45 \mu \mathrm{m})$ and the partial purified bacteriocin like substances designated as PPBLS and stored at $-20^{\circ} \mathrm{C}$ for further use. Protein content in the supernatant was determined according to Lowry (1951) [26] using bovine serum albumin as the standard.

\subsection{Antifungal Activity of Bacteriocin against the Growth and Spore Germination of Penicillium candidum}

The antifungal activity of PPBLS against $P$. candidum was determined by agar well diffusion and growth inhibition methods. For agar well diffusion method, potato dextrose agar medium (PDA) was poured into sterilized Petri dishes, left to solidify at room temperature $\left(22^{\circ} \mathrm{C}\right)$, and then swabbed from fresh fungal culture strain. Wells in the centre of agar plates were created using a sterile cork borer $(9 \mathrm{~mm})$ and different concentrations of PPBLS (2, 4 and $8 \mathrm{mg} / \mathrm{ml})$, were transferred to the wells. Plates were incubated at $28^{\circ} \mathrm{C}$ for 72 $\mathrm{h}$. The antifungal activity was determined by measuring the clear zones diameter (CZD) around each well in $\mathrm{mm}$. Distilled water was used as a control.
Regarding growth inhibition percentage of $P$. candidum as affected by PPBLS of strain LAB 100, serial of two-fold concentrations $(2,4,8,16$ and $32 \mathrm{mg} / \mathrm{ml})$ of PBLS were pipetted into the melted PDA medium and well mixed, then poured into sterilized Petri dishes and left to solidify at room temperature $\left(22^{\circ} \mathrm{C}\right)$. The fungal discs $(9 \mathrm{~mm})$ were transferred into the centre of containing PPBLS plates, and incubated at $28^{\circ} \mathrm{C}$ for $72 \mathrm{~h}$. The inhibition percentage (\%) was calculated by using the formula given below:

Inhibition $(\%)=\frac{C-T \times 100}{C}$ where, $\mathrm{C}$ : Control (Diameter of the fungal growth on potato dextrose agar without PPBLS), $\mathrm{T}$ : Test (Diameter of fungal growth grown on PDA containing different PPBLS concentration).

To determine the effect of the partial purified Bacteriocin of isolate LAB100 on P. candidum spores germination; PDA slant medium was inoculated with the fungal culture and incubated at $28^{\circ} \mathrm{C}$ for $72 \mathrm{~h}$. The spores were collected by flooding the fungal slant culture with sterile saline solution containing $0.01 \% \quad(\mathrm{v} / \mathrm{v})$ Tween 80 , and then shaken vigorously to liberate the spores. To separate the fungal spores from the hyphae, solution was filtered through 4 consecutive sterile absorbent cotton wool plugs to remove any hyphal fragments present. The spores were treated with different concentrations $(2,4,8,16$ and $32 \mathrm{mg} / \mathrm{ml})$ of PPBLS and incubated at $28^{\circ} \mathrm{C}$ for overnight, and then the germination was checked by inoculation on PDA plates and incubation for $72 \mathrm{~h}$.

\subsection{Camembert Cheese Starter Cultures}

Both lyophilized starter culture and Mould strain were obtained from IP Ingredient GmbH, Germany. Mesophilic multiple-species DL-culture DL-Mix M FZ 2-22 (MK); contain microorganisms of Lactococcus lactis subsp. lactis, Lactococcus lactis subsp. cremoris, Lactococcus lactis subsp. lactis biovar. diacetylactis and Leuconstoc mesenteroides subsp. cremoris. The freeze dried bacterial strains were prepared in sterilized skim milk, 1 day before manufacture and used with concentration of $1.5 \%$ of manufacture milk. Penicillium candidum (P. candidum) was prepared in sterilized saline contain 5\% Tween 80 to make the spores more homogeneous and good distributed in milk, this saline shacked for 1 day before manufacture on mechanical shaker.

\subsection{Source of Fresh Cows' Milk and Rennet}

Fresh cows' milk was obtained from the dairy processing pilot plant of the Faculty of Agriculture, Fayoum University, Egypt. Rennet powder (Hanelase) was obtained from Chr. Hansen's Lab., Denmark.

\subsection{Manufacturing Procedure}

Manufacture of Camembert cheese was done according to Galloway, (1995) [27]. The resultant cheeses were salted in saturated brine solution (its $\mathrm{pH}$ was adjusted to 5-5.3) for $1 \mathrm{hr}$. at $14^{\circ} \mathrm{C}$. Then it's ripened at $12 \pm 2{ }^{\circ} \mathrm{C}$ and $90-95 \%$ relative humidity (R. H.) for 10 days or until mould growth was shown. After two weeks of ripening all cheese treatments 
packaged and kept at $5 \pm 2{ }^{\circ} \mathrm{C}$ until the end of ripening period (40 days). The treatments were: Camembert cheese made with traditional method (T1: control), cheese made with bacteriocin producer isolate LAB 100 (T2) added as coculture, T3: cheese made with both LAB100 and further sprayed with PPBLS after 3 days of brining, T4: cheese made with both LAB100 and further sprayed with PPBLS after 10 days of brining. Samples of previous Camembert cheese treatments were taken during ripening, at ages of $3,10,20$, and 40 days; for determining nitrogen distribution, $\mathrm{pH}$ values, rate of proteolysis, microbiological and organoleptic properties.

\subsection{Organoleptic Evaluation}

Camembert cheese samples (age 40 days), were served at room temperature $\left(28^{\circ} \mathrm{C}\right)$ to evaluate the organoleptic properties by the stuff members of Dairy Science Department, Fayoum University, Egypt. Score card was as follows: Flavor (35 points), body and texture (35 points), colour and appearance (30 points), which give total scores of (100 points). Experimental data were statistically analyzed using general linear models of SPSS (1999) [28]. Mean of the values, were compared with main effects by Duncan's multiple range tests [29] when significant $F$ values were obtained $(\mathrm{P} \leq 0.01)$.

\subsection{Assessment of Proteolysis during Ripening}

Proteolysis of Camembert cheese treatments was determined during ripening using Urea-Polyacrylamide gel electrophoresis (Urea-PAGE) according to the method of Andrews (1983) [30]. Lyophilized cheese (20 mg) was dissolved in $1.0 \mathrm{ml}$ of sample buffer and then heated in water bath at $40^{\circ} \mathrm{C}$ for $1 \mathrm{hr}$., and then $17 \mu \mathrm{l}$ was into the gel. The resultant gel was stained directly by the method of Blaksley and Boezi (1977) [31]. Also Total nitrogen (TN) and water soluble nitrogen (WSN) were determined by macro-Kjeldahl method according to AOAC (2000) [32], using Gerhardt equipment, type VAP 200 (Germany). Values of $\mathrm{pH}$ for Camembert cheese samples were measured during ripening potentiometrically according to Peláez et al., (2003) [33], using pH meter Thermo Scientific Orion Star (A214).

\subsection{Microbiological Examination}

Samples of all Camembert cheese treatments were prepared for microbiological examination according to (Marshall, 1992) [34]. One gram of each Camembert cheese treatments was smashed for two minutes with $1 \mathrm{ml}$ of sterilized sodium citrate solution $(20 \%)$ in a sterilized mortar and then $8 \mathrm{ml}$ of sterilized saline was added under sterilized conditions. Further decimal dilutions were prepared in sterilized saline, the samples were examined for yeasts \& moulds count at ages of 3,10,20 and 40 days of ripening. The media used were in a dehydrated form and prepared according to the manufacturer's instructions. Yeasts and moulds count were determined according to Tatini et al., (2003) [35], using potato dextrose agar, and the plates were incubated at $25^{\circ} \mathrm{C}$ for 5 days.

\section{Results and Discussion}

\subsection{Genotypic and Phenotypic Characterization of Isolate LAB 100}

In this study, 120 Lactic acid bacterial isolates were isolated from local fermented dairy products and screened for bacteriocin production in the term of antifungal activity against $P$. candidum using agar-well diffusion method. Based on their superior antimicrobial potential activity, isolate LAB100 was chosen for further phenotypic and genotypic characterization. This isolate exhibited broad spectrum antimicrobial activity against wide range of microorganisms including; Gram positive, negative bacteria, as well was $P$. candidum. However, in this study we focused only on using the strain LAB100 as co-starter/ or its bacteriocin for minimizing and delaying the growth of $P$. candidum to control the Camembert cheese over-ripening. Isolate LAB100 was Gram-positive, oxidase and catalase-negative, facultative aerobic, non-motile, non-spore-forming regular single rods, pairs or rarely short chains. Temperature and $\mathrm{pH}$ optimum for growth were around $37^{\circ} \mathrm{C}$ and 6.4 , respectively. The ability of isolate LAB100 to utilize different carbon sources and its enzyme activities was investigated by using API 50 CHL kit. The data in Table (1) showed that this isolate could utilize a wide range of sugars and differ from related similar strains in some sugars. However, it was reported that the identification of Lactobacillus spp. by biochemical methods alone is not always reliable [36]. Therefore, the phylogenetic relationships of isolate LAB100 and the lactobacilli were confirmed by comparing the $16 \mathrm{~s}$ rDNA genes. The phylogenetic dendogram (Figure 1) showed that Lactobacillus casei and Lactobacillus paracasei and Lactobacillus rhamnosus were the nearest phylogenetic neighbors for isolate LAB 100 with a similarity of $95 \%$.

The distinctness of LAB100 from the related neighbors is supported by physiological characteristics, such as their ability or inability to utilize L-Arabinose, D-xylose, Rhamnose, Inositol, Melibiose, Melezitose, Raffinose, DTagtose and D-arabitol. However, the phenotypic results in Table (1) and the analysis of phylogenetic dendogram (Figure 1) showed that isolate $\mathrm{LAB} 100$ distinct from the nearest neighbors in separate subcluster, suggesting that this isolate could be identified as new species of the genus Lactobacillus. In this context, Collwell et al. (1995) [37] reported that "a bacterial species is generally considered to be a collection of strains that show a high degree of overall similarity and differ considerably from related strain groups with respect to many independent characteristics".

\subsection{Antimicrobial Activity of PPBLS against Penicillium candidum}

Among 120 LAB strains tested against $P$. candidum, bacteriocin of LAB100, recorded the highest antifungal activity as indicated by the formation of clear zone diameter. 
Table 1. API 50CHL carbohydrate profile for isolate LAB100.

\begin{tabular}{|c|c|c|c|c|}
\hline \multirow{2}{*}{\multicolumn{2}{|c|}{ Carbon sources }} & \multicolumn{3}{|c|}{ Reference strains ${ }^{(*)}$} \\
\hline & & \multirow{2}{*}{$\begin{array}{l}\text { LAB100 } \\
+++\end{array}$} & \multirow{2}{*}{$\begin{array}{l}\text { L. paracasei } \\
+++\end{array}$} & \multirow{2}{*}{$\begin{array}{l}\text { L. rhamnosus } \\
-\end{array}$} \\
\hline 1 & Glycerol & & & \\
\hline 2 & Erythritol & - & - & - \\
\hline 3 & D-Arabinose & - & - & +++ \\
\hline 4 & L-Arabinose & - & +++ & + \\
\hline 5 & Ribose & +++ & +++ & ++ \\
\hline 6 & D-Xylose & - & +++ & - \\
\hline 7 & L-Xylose & - & - & - \\
\hline 8 & Adonitol & - & - & - \\
\hline 9 & $\beta$-Methyl-D-Xyloside & - & - & - \\
\hline 10 & Galactose & +++ & +++ & +++ \\
\hline 11 & Glucose & +++ & +++ & +++ \\
\hline 12 & Fructose & +++ & +++ & +++ \\
\hline 13 & Mannose & +++ & +++ & ++ \\
\hline 14 & Sorbose & - & - & - \\
\hline 15 & Rhamnose & +++ & - & +++ \\
\hline 16 & Dulcitol & - & - & - \\
\hline 17 & Inositol & +++ & - & - \\
\hline 18 & Mannitol & +++ & +++ & +++ \\
\hline 19 & Sorbitol & +++ & +++ & +++ \\
\hline 20 & $\alpha$-Methyl-D-Mannoside & - & - & + \\
\hline 21 & $\alpha$-Methyl-D-Glucoside & - & - & - \\
\hline 22 & $\mathrm{~N}$-acetyl-glucosamine & +++ & +++ & +++ \\
\hline 23 & Amygdalin & +++ & +++ & +++ \\
\hline 24 & Arbutin & +++ & +++ & +++ \\
\hline 25 & Esculin Hydrolysis & +++ & +++ & ++ \\
\hline 26 & Salicin & +++ & +++ & +++ \\
\hline 27 & Cellobiose & +++ & +++ & +++ \\
\hline 28 & Maltose & +++ & +++ & +++ \\
\hline 29 & Lactose & +++ & +++ & +++ \\
\hline 30 & Melibiose & - & +++ & +++ \\
\hline 31 & Sucrose & ++ & +++ & +++ \\
\hline 32 & Trehalose & +++ & +++ & +++ \\
\hline 33 & Inulin & - & - & - \\
\hline 34 & Melezitose & +++ & - & +++ \\
\hline 35 & Raffinose & - & +++ & + \\
\hline 36 & Starch hydrolysis & - & - & - \\
\hline 37 & Glycogen & - & - & - \\
\hline 38 & Xylitol & - & - & - \\
\hline 39 & Gentiobiose & ++ & +++ & +++ \\
\hline 40 & D-Turanose & +++ & +++ & +++ \\
\hline 41 & D-Lyxose & - & - & - \\
\hline 42 & D-Tagatose & +++ & - & - \\
\hline 43 & D-Fucose & - & - & - \\
\hline 44 & L-Fucose & - & - & - \\
\hline 45 & D-Arabitol & - & - & +++ \\
\hline 46 & L-Arabitol & - & - & - \\
\hline 47 & Gluconate & ++ & +++ & +++ \\
\hline 48 & 2-Keto-gluconate & - & - & - \\
\hline 49 & 5-Keto-gluconate & - & - & - \\
\hline
\end{tabular}

Notes: Carbohydrate fermentation profiles were applied according to API 50 CHL strips (BioMéríeux, Lyon /France). The Score of the result tests:-negative growth; + weak growth; ++good growth, +++ very good growth. $\left(^{*}\right)=$ Reference strains of Lactobacillus rhamnosus and Lactobacillus paracasei obtained from culture collection of department of Agricultural Microbiology and Biotechnology, Faculty of Agriculture, Fayoum University, Egypt. 


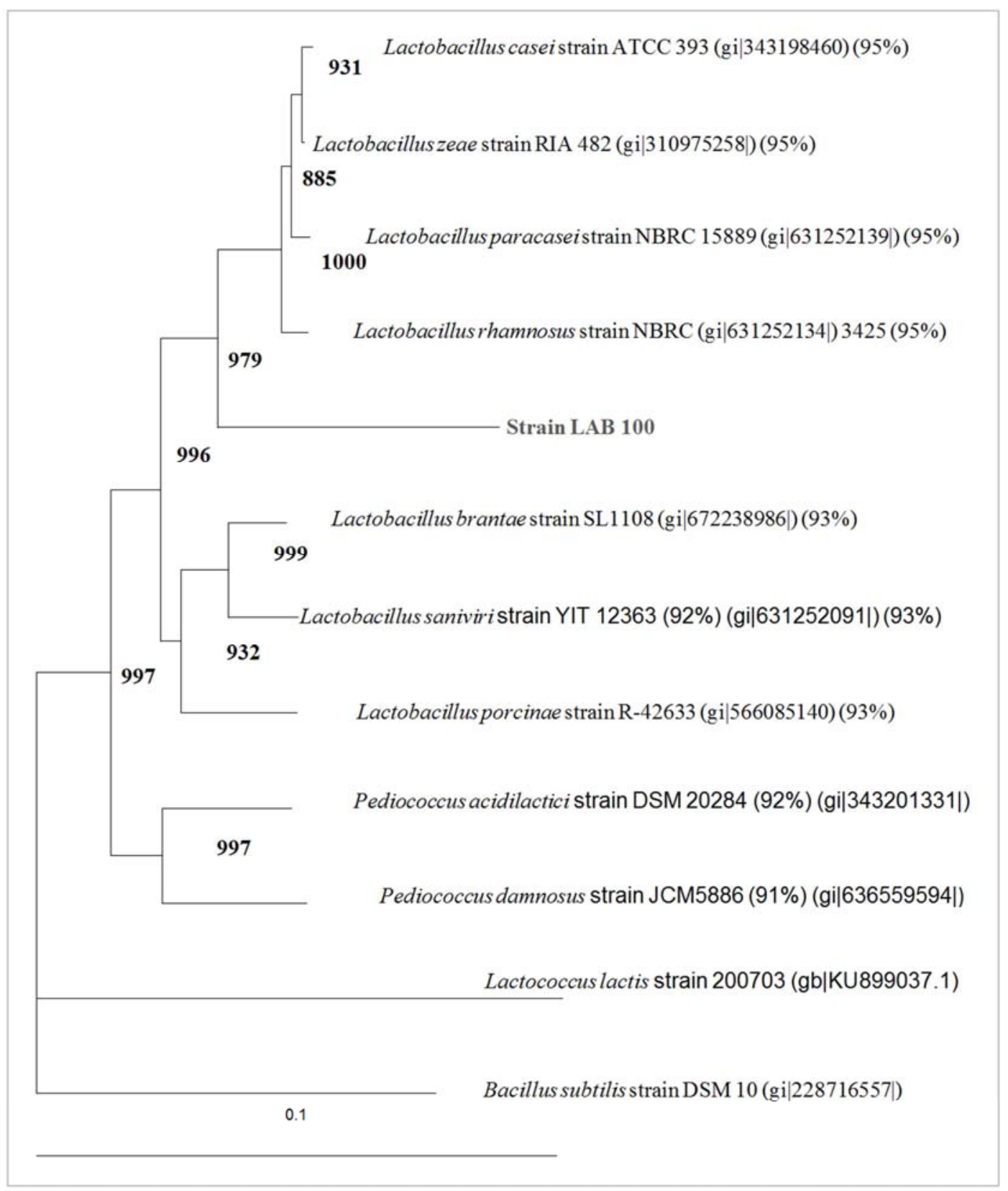

Figure 1. Neighbor-joining tree showing the estimated phylogenetic relationships of the Lactobacillus sp. LAB100 and other closely-related strains of the genus Lactobacillus. Bootstrap values out of 1000 are given at the nodes. Bacillus subtilis strain DSM 10 (gi|228716557) and Lactococcus lactis strain 200703 (gb|KU899037.1) as out group.

Table 2. Inhibitions (\%) of Penicillium candidum by PPBLS of isolate LAB 100.

\begin{tabular}{llll}
\hline \multirow{2}{*}{ PPBLS concentration $(\mathbf{m g} / \mathbf{m l})$} & Inhibition of P. candidum by PPBLS & & Spores germination \\
\cline { 2 - 4 } & P. candidum growth diameter $(\mathbf{m m})$ & Inhibition $(\%)$ & + \\
\hline 0.0 & 100 & 0.0 & \pm \\
2 & 66 & 34 & - \\
4 & 50 & 50 & - \\
8 & 21 & 79 & - \\
16 & 20 & 80 & - \\
32 & 15 & 85 & \\
\hline
\end{tabular}

Notce: To determine the inhibition percentage of Penicillium candidum as affected by PPBLS of strain LAB 100, serial of two-fold concentrations $(2,4,8,16$ and $32 \mu \mathrm{g} / \mathrm{ml}$ ) of PBLS were pipetted into the melted PDA medium and well mixed, then poured into sterilized Petri dishes and left to solidify at room temperature $\left(22^{\circ} \mathrm{C}\right)$. The fungal discs $(9 \mathrm{~mm})$ were transferred into the centre of containing PPBLS plates, and incubated at $28^{\circ} \mathrm{C}$ for $72 \mathrm{~h}$. The inhibition percentage (\%) was calculated by using the formula given below:

Percentage inhibition $=\frac{C-T \times 100}{C}$, where: $\mathrm{C}=\mathrm{Control}$ (Diameter of the fungal growth on potato dextrose agar without PPBLS), $\mathrm{T}=$ Test (Diameter of fungal growth grown on PDA containing different PPBLS concentration) 

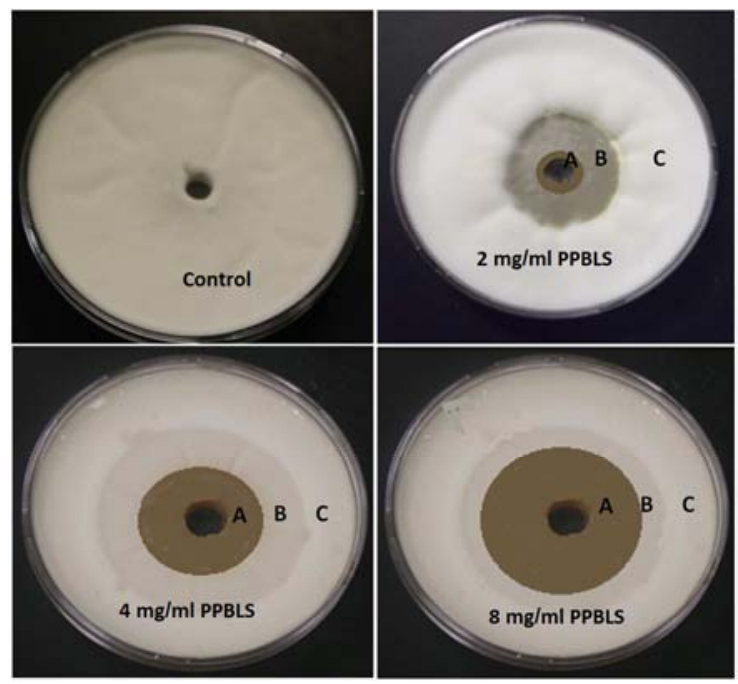

Figure 2. Antimicrobial activities of PPBLS from isolate LAB100 as indicated by clear zone diameter $(\mathrm{mm})$.

Notes: The antifungal activity of PPBLS against Penicillium candidum was determined by agar well diffusion. PPBLS of isolate LAB100 exhibited three inhibition zones, the first one (A): clear zone (no growth), the second one (B) inducted growth of the fungal mycelia without spores that called mycelia sterilia (mycelium with no reproductive structures), the third zone (C) showing normal growth (mycelia and spores).
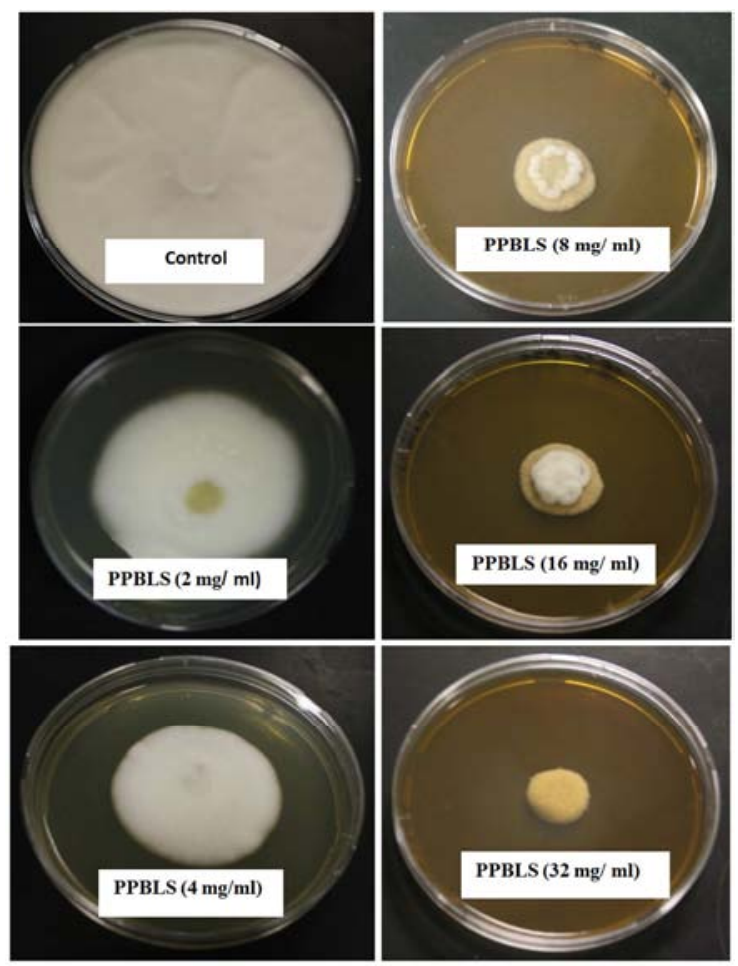

Figure 3. Growth Inhibition of Penicillium candidum by PPBLS purified from isolate LAB100 indicated by growth diameter $(\mathrm{mm})$.

Notce: To determine the inhibition percentage of Penicillium candidum as affected by PPBLS of strain LAB 100, serial of two-fold concentrations (2, 4, 8 , 16 and $32 \mathrm{mg} / \mathrm{ml}$ ) of PBLS were pipetted into the melted PDA medium and well mixed, then poured into sterilized Petri dishes and left to solidify at room temperature $\left(22^{\circ} \mathrm{C}\right)$. The fungal discs $(9 \mathrm{~mm})$ were transferred into the centre of containing PPBLS plates, and incubated at $28^{\circ} \mathrm{C}$ for $72 \mathrm{~h}$. The inhibition percentage (\%) was calculated by using the formula given below Table (2).
As shown in Figure (2), it was noticed that, the antifungal activity of PPBLS against $P$. candidum was increased as the PPBLS concentration increased, whereas at 2, 4 and $8 \mathrm{mg} / \mathrm{ml}$ of PPBLS revealed clear zones 12, 37 and $50 \mathrm{~mm}$, respectively. Interesting findings in this study that, the PPBLS of isolate LAB100 exhibited three inhibition zones, the first one: clear zone (no growth), the second one inducted growth of the fungal mycelia without spores that called mycelia sterilia (mycelium with no reproductive structures), the third zone showing normal growth (mycelia and spores). Worth mentioning that, no growth was observed when new agar plates or broth media were inoculated with loop from the clear zone area, indicating that the PPBLS of LAB100 have lethal effects. In addition, when the $P$. candidum spores were soaked in different concentrations of PPBLS $(2,4,8,16$ and $32 \mathrm{mg} / \mathrm{ml}$ ), then plated on PDA, no spore germination was observed when checked by inoculation on PDA plates. Only weak growth was observed at low concentration of 2 $\mathrm{mg} / \mathrm{ml}$ of PPBLS (Table 2).

Data in Table (2) and Figures (3) show inhibition (\%) of $P$. candidum as controlled by the PPBLS of strain LAB100. It was observed that when the PPBLS was supplemented in PDA medium, the growth of $P$. candidum was significantly controlled and as the concentration of PPBLS increased, the fungal growth was degreased. Inhibition (\%) of $P$. candidum by PPBLS at concentrations of 2, 4, 8, 16 and $32 \mathrm{mg} / \mathrm{ml}$ was $34,50,79,80$ and $85 \%$, respectively. These results proposed that to control the over-ripening of Camembert cheese by the PPBLS, the concentration at $8 \mathrm{mg} / \mathrm{ml}$ was the most suitable one to minimize the growth of $P$. candidum. The antifungal activity of the neutralized, catalase treated, and partial purified bacteriocin in this study indicated that the major antibacterial activity was most likely due to their antimicrobial peptides not to organic acids or hydrogen peroxide produced by LAB strains. In this context, it was reported that $\mathrm{LAB}$ display a wide range of antimicrobial activities. Amongst these activities, the production of lactic acid and acetic acid were obviously the most important. However, certain strains of LAB are further known to produce bioactive molecules such as ethanol, formic acid, fatty acids, hydrogen peroxide, diacetyl, reuterin, and reutericyclin. Many strains also produce bacteriocins and bacteriocin-like molecules that display antibacterial activity [38-40]. Bacteriocins are generally considered to act at the cytoplasmic membrane and dissipate the proton motive force through the formation of pores in the membrane. It was reported that antimicrobial peptides may have diverse mechanisms of action, but the cytoplasmic membrane is the target for most bacteriocins. However, some structures are specific for fungi, such as the chitin and $\beta$-glucan in the cell wall and ergosterol in the cell membrane. Many antifungal inhibitors have a specific site for their inhibitory action. Common targets are the cell wall, the cell membrane, protein synthesis or cell division. Inhibition of $\beta$-glucan synthesis and inhibition of chitin synthetase are the main mechanisms of compounds that act on the fungal cell wall [41-43]. 
However, even though bacteriocin has been widely used in food preservation and medical applications, they are still limited to control or retardation of Camembert cheese over ripening.

\subsection{Organoleptic Evaluation}

Data in Table (3) shows the sensory evaluation of Camembert cheese treatments; from organoleptic evolution; the panelists comment that, T1 had a very bitter taste and the consistency was liquefied comparing to other Camembert cheese treatments that contain bacteriocin producing bacteria. Data in Table (3) shows a significant difference $(\mathrm{P} \leq 0.05)$ between Camembert cheese control and other cheese treatments made with adding bacteriocin producing bacteria (LAB100). The highest parameters scores was for cheese treatment that treated by lactic acid bacteria produces bacteriocin (T2), where flavor was (32.33), body \& texture (32.9), color and appearance (28.3) and the final total score points (94.4), followed by $\mathrm{T} 3$ and $\mathrm{T} 4$, both had final total scores of $88.6,88.0$, respectively. On the other hand the lowest scores were recorded for cheese control (T1), where flavor, body \& texture, color and appearance and the final total score points were 22.7, 28.6, 26.5 and 77.8. These results confirm that adding lactic acid bacteria (LAB100) producing bacteriocin or using both LAB100 and further sprayed with PPBLS delayed the growth of $P$. candidum and the rate of proteolysis decreased and no bitter flavor appeared comparing to control.

\subsection{Quantitation of Proteolysis during Cheese Ripening}

\subsubsection{Nitrogen Distribution and $\mathrm{pH}$ Values}

Data in Table (4), explained the total nitrogen, total protein, WSN, WSN/TN\% and $\mathrm{pH}$ of Camembert cheese samples. There was a significant difference $(\mathrm{P} \leq 0.05)$ in $\mathrm{TN}$ and consequently total protein content in Camembert cheese treatments during ripening period, both were increasing in all cheese treatments may because of moisture decreasing with progress of storage. Total $\mathrm{N}$ in Camembert cheese treatments in fresh and ripened cheese was ranging from 3.09 to $3.59 \%$, respectively. These results were in agreement with Khider (1995) [44], who found that TN was 2.5 and 3.5 for fresh and ripened cheese (40 days), respectively. It was also noticed that there was a significant differences $(\mathrm{P} \leq 0.001)$ in the water soluble nitrogen (WSN) content of different Camembert cheese treatments. In general WSN was increasing as ripening period progressed, this could be related to the extracellular proteinases of the surface mould; which become active during weeks 2 to 4 of ripening leading to a rapidly increase in water soluble nitrogen. From these results we found that cheese control was more ripened than other cheese treatments; which indicated by the increase in both $\mathrm{pH}$ values and $\mathrm{WSN} / \mathrm{TN} \%$ with progress of ripening time.
Table 3. Organoleptic Evaluation of different Camembert cheese treatments (4 weeks age).

\begin{tabular}{lllll}
\hline Sample No. & Flavor (35) & Body\&Texture (35) & Color (30) & Total (100) \\
\hline T1 & $22.7^{\mathrm{b}}$ & $28.6^{\mathrm{b}}$ & $26.5^{\mathrm{a}}$ & $77.8^{\mathrm{b}}$ \\
$\mathrm{T} 2$ & $32.33^{\mathrm{a}}$ & $32.9^{\mathrm{a}}$ & $28.3^{\mathrm{a}}$ & $94.4^{\mathrm{a}}$ \\
$\mathrm{T} 3$ & $30.9^{\mathrm{a}}$ & $30.7^{\mathrm{a}}$ & $27.0^{\mathrm{a}}$ & $88.6^{\mathrm{a}}$ \\
$\mathrm{T} 4$ & $29.5^{\mathrm{a}}$ & $31.0^{\mathrm{a}}$ & $27.5^{\mathrm{a}}$ & $88.0^{\mathrm{a}}$ \\
$\mathrm{SE} \pm$ & 1.24 & 1.04 & 0.773 & 2.43 \\
\hline
\end{tabular}

T1: Camembert cheese with traditional method (control), T2: Camembert cheese made with bacteriocin producer isolate LAB 100, T3: Camembert cheese made with both LAB100 and further sprayed with PPBLS after 3 days of brining, T4: Camembert cheese made with both LAB100 and further sprayed with PPBLS after 10 days of brining.

The highest values of WSN/TN\% was; 5.4, 22.87, 34.41 and $57.65 \%$ for $\mathrm{T} 1$, at $3,10,20$, and 40 days, respectively. These results were in close to what found by Katoka et al., (1987) [45]; where they recorded that $79 \%$ of total nitrogen was soluble from 2-4 weeks of ripening. In our study the lowest WSN/TN\% was found in treatment that made with adding the isolate produces bacteriocin and treated by bacteriocin solution after 3 days of brining; where it was $5.05,9.85,13.82$, and $31.74 \%$ for $\mathrm{T} 3$ at the same previous ages, respectively. From these results we concluded that ripening process was limited by using lactic acid bacteria produces bacteriocin with spray the surface of the cheese by bacteriocin solution after 3 days of brining, and cheese treatment that was more extensive proteolysis was for control (T1), followed by T4 and the less proteolysis one is T3. From these results it is obvious that using the isolate which produces bacteriocin (LAB100) with the main starter or using both LAB100 and further sprayed with PPBLS after 3 days of brining; minimize the growth of $P$. candidum during ripening comparing to control.

Table (4) shows changing in $\mathrm{pH}$ values of Camembert cheese treatments during ripening. The $\mathrm{pH}$ values were increasing during ripening as a result of proteolysis occurred by proteinases from $P$. candidum during ripening and producing ammonia. There was a significant difference $(\mathrm{P} \leq 0.001)$ in $\mathrm{pH}$ values during ripening period and between cheese treatments; it increases with the progress of ripening period, and that was rapidly occurred in cheese control after 10 days of ripening (Table 4). The highest $\mathrm{pH}$ values was; 4.5, 4.8, 6.07 and 6.05 for cheese control (T1) at 3,10,20 and 40 days of ripening, respectively, while the lowest $\mathrm{pH}$ values were; 4.4, 4.6, 5.1 and 5.5 for $\mathrm{T} 4$ at same previous periods, respectively. These results was close to that found by Khidr (1995) [44], who found that $\mathrm{pH}$ values ranged from 4.7 to 6.6 during ripening period from fresh to 40 days, respectively. Regarding these results it is obvious that using bacteriocin producing bacteria as co-culture, or using both LAB100 and further sprayed with PPBLS after 3 days or 10 days of brining; minimize the growth of the mould in T2, T3 and T4, respectively, comparing to control treatment. 


\subsubsection{Assessment of Camembert Cheese Proteolysis by Gel Electrophoresis}

Figure (4) explains the rate of proteolysis in Camembert cheese during ripening period. The first three bands from the top of the gel may correspond to $\gamma$-caseins ( $\beta$-casein $\mathrm{f} 106-209$, f29209 and $\mathrm{f}$ 108-209 f for $\gamma_{2}, \gamma_{1}$ and $\gamma_{3}$, respectively); which resulted from the action of plasmin on $\beta$-casein. The $\gamma$-caseins were more intense and the intensity was increased with ripening time, because the $\mathrm{pH}$ approached near to neutrality which is suitable for plasmin action. The band $\beta-\mathrm{CN}\left(\mathrm{fl}-^{*}\right)$ may resulted from the action of fungal proteinases on $\beta$-casein; which was more degraded by progress of ripening as shown in the electrophotogram. It is also noticed that residual $\alpha \mathrm{s}_{1}$-casein was more degraded during ripening than $\beta$-casein by the action of surface flora. The band represents $\alpha_{\mathrm{s} 1}-\mathrm{CN}$ (Figure 4), is more degraded in control treatment (T1) at 20 days of ripening than in the other Camembert cheese treatments. The band $\alpha_{\mathrm{s} 1}-\mathrm{CN}$ (f33*) was increased in all cheese treatments by the progress of ripening. The band which may represents $\alpha_{\mathrm{s} 1}-\mathrm{CN}$ (f $60-^{*}$ ) was shown in $\mathrm{T} 1$ after 20 days of ripening and not shown in the other Camembert cheese treatments (T2, T3 and T4) at the same age, but later appeared after 40 days of ripening in these previous treatments. This may resulted from the action of fungal proteinases because the rate of proteolysis in $\mathrm{T} 1$ was more intense than in the other Camembert cheese treatments; where the growth of $P$. candidum in T2, T3 and T4 could be affected by the action of bacteriocin producing bacteria and make the fungal growth limited. The previous band $\alpha_{\mathrm{s} 1} \mathrm{CN}$ (f $60-^{*}$ ) was later started to degrade and decrease in $\mathrm{T} 1$ at 40 days age of ripening, probably as a result of the action of proteinases and peptidases from the surface flora because with ripening progresses; the $\mathrm{pH}$ increased and this not suitable for chymosin action.

Table 4. Effect of using bacteriocin producing bacteria and/or bacteriocin solution spray on chemical composition of camembert cheese during ripening period.

\begin{tabular}{|c|c|c|c|c|c|c|}
\hline \multirow{2}{*}{ Treatments } & \multirow{2}{*}{ Ripening period (day) } & \multicolumn{5}{|c|}{ Chemical composition } \\
\hline & & TN \% & TP\% & WSN\% & WSN/TN\% & pH \\
\hline \multirow{4}{*}{$\mathrm{T} 1$} & Fresh & $3.09^{\mathrm{G}}$ & $19.71^{\mathrm{G}}$ & $0.167^{\mathrm{J}}$ & 5.4 & $4.5^{\mathrm{IJ}}$ \\
\hline & 10 & $3.24^{\mathrm{E}}$ & $20.65^{\mathrm{E}}$ & $0.74^{\mathrm{F}}$ & 22.87 & $4.8^{\mathrm{G}}$ \\
\hline & 20 & $3.39^{\mathrm{C}}$ & $21.63^{C}$ & $1.167^{\mathrm{D}}$ & 34.41 & $6.07^{\mathrm{B}}$ \\
\hline & 40 & $3.51^{\mathrm{B}}$ & $22.39^{\mathrm{B}}$ & $2.023^{\mathrm{A}}$ & 57.65 & $6.5^{\mathrm{A}}$ \\
\hline \multirow{4}{*}{$\mathrm{T} 2$} & Fresh & $3.1^{\mathrm{FG}}$ & $19.799^{\mathrm{FG}}$ & $0.157^{\mathrm{J}}$ & 5.07 & $4.4^{\mathrm{J}}$ \\
\hline & 10 & $3.27^{\mathrm{DE}}$ & $20.88^{\mathrm{DE}}$ & $0.537^{\mathrm{G}}$ & 16.39 & $4.7^{\mathrm{H}}$ \\
\hline & 20 & $3.39^{\mathrm{C}}$ & $21.649^{\mathrm{C}}$ & $1.038^{\mathrm{E}}$ & 30.6 & $5.5^{\mathrm{D}}$ \\
\hline & 40 & $3.59^{\mathrm{A}}$ & $22.84^{\mathrm{A}}$ & $1.883^{\mathrm{B}}$ & 52.61 & $5.8^{\mathrm{C}}$ \\
\hline \multirow{4}{*}{$\mathrm{T} 3$} & Fresh & $3.11^{\mathrm{FG}}$ & $19.84^{\mathrm{FG}}$ & $0.157^{\mathrm{J}}$ & 5.048 & $4.4^{\mathrm{J}}$ \\
\hline & 10 & $3.28^{\mathrm{D}}$ & $20.95^{\mathrm{D}}$ & $0.323^{\mathrm{I}}$ & 9.848 & $4.6^{\mathrm{HI}}$ \\
\hline & 20 & $3.4^{\mathrm{C}}$ & $21.69^{C}$ & $0.47^{\mathrm{H}}$ & 13.82 & $5.1^{\mathrm{F}}$ \\
\hline & 40 & $3.55^{\mathrm{AB}}$ & $22.65^{\mathrm{AB}}$ & $1.127^{\mathrm{D}}$ & 31.74 & $5.5^{\mathrm{D}}$ \\
\hline \multirow{5}{*}{$\mathrm{T} 4$} & Fresh & $3.14^{\mathrm{F}}$ & $20.01^{F}$ & $0.158^{\mathrm{J}}$ & 5.028 & $4.4^{\mathrm{J}}$ \\
\hline & 10 & $3.28^{\mathrm{D}}$ & $20.95^{\mathrm{D}}$ & $0.317^{\mathrm{I}}$ & 9.647 & $4.6^{\mathrm{HI}}$ \\
\hline & 20 & $3.39^{\mathrm{C}}$ & $21.63^{C}$ & $0.483^{\mathrm{GH}}$ & 14.26 & $5.3^{\mathrm{E}}$ \\
\hline & 40 & $3.58^{\mathrm{A}}$ & $22.84^{\mathrm{A}}$ & $1.573^{\mathrm{C}}$ & 43.95 & $5.7^{\mathrm{C}}$ \\
\hline & $\mathrm{SE} \pm$ & 0.014 & 0.92 & 0.021 & 0.625 & 0.036 \\
\hline
\end{tabular}

T1: Camembert cheese with traditional method (control), T2: Camembert cheese made with bacteriocin producer isolate LAB 100, T3: Camembert cheese made with both LAB100 and further sprayed with PPBLS after 3 days of brining, T4: Camembert cheese made with both LAB100 and further sprayed with PPBLS after 10 days of brining.

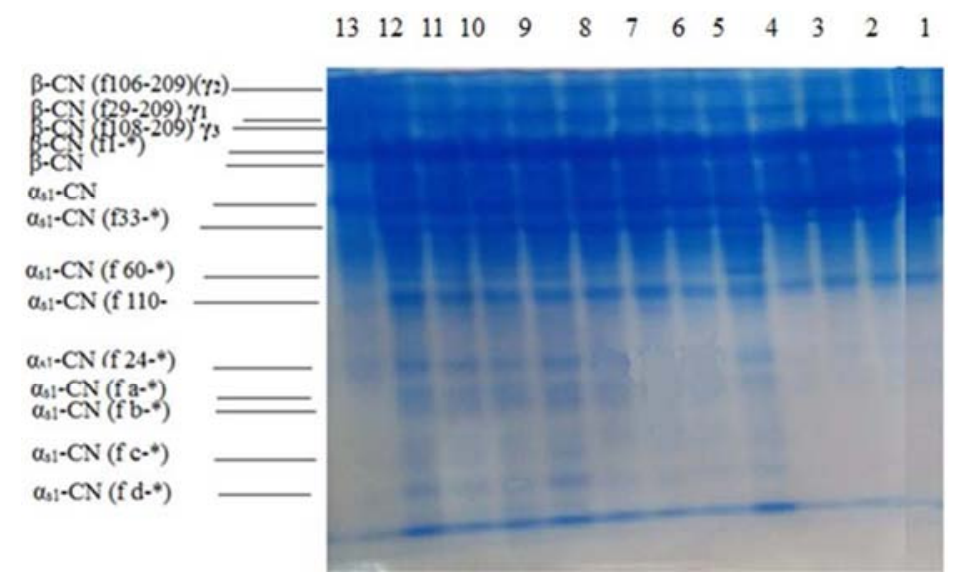

Figure 4. Urea-PAGE Electrophotograms of Camembert Cheese during Ripening periods.

Lanes, 1, 2, 3 and 4: (T1-T4 at age 3 days after brining), Lanes 5, 6, 7 and 8: T1-T4 at age 20 days after brining, Lanes 9, 10, 11 and 12: T1-T4 at age 40 days after brining, Lane 13: represent casein standard. *Unknown fraction.

T1: Camembert cheese with traditional method (control), T2: Camembert cheese made with bacteriocin producer isolate LAB 100, T3: Camembert cheese made with both LAB100 and further sprayed with PPBLS after 3 days of brining, T4: Camembert cheese made with both LAB100 and further sprayed with PPBLS after 10 days of brining. 
From the electrophotogram (Figure 4) it is noticed that rate of proteolysis at 40 days of ripening was high in cheese control (T1), then followed by T4. While, less proteolysis rate was in cheese treatments $\mathrm{T} 2$ and $\mathrm{T} 3$ and they also more similar in the intensity of proteolysis. Regarding these results, $P$. candidum growth in treatment made with traditional method was in normal mode, but it was minimize by using bacteriocin producer isolate (LAB100) (T2) and also in treatment which made with both LAB100 and further sprayed with PPBLS after 10 days of brining (T4). Moreover, the growth of $P$. candidum was minimized more by using both LAB100 and further sprayed with PPBLS after 3 days of brining (T3) as indicated by less proteolysis than previous treatments; as shown in Figure (4) where, $\alpha_{\mathrm{s} 1}-\mathrm{CN}$ (f d-*) after 40 days of ripening was shown in Control (T1) and was a little intense in $\mathrm{T} 4$, but not shown in $\mathrm{T} 2$ or $\mathrm{T} 3$.

\subsection{Microbiological Examination}

The maximum growth of yeast and moulds (Table 5), was noticed after 20 day, and then decreased. The counts were decreasing during ripening in all cheese treatments; the lowest one was in T3, where recorded 7.49 and $6.76 \log \mathrm{CFU} / \mathrm{gm}$ at 15 and 40 days of ripening, respectively. While, the highest count was 8.88 and $8.39 \log \mathrm{CFU} / \mathrm{gm}$ at 20 and 40 days of ripening, respectively for control $\mathrm{T} 1$. The low numbers of yeast and moulds that noticed in $\mathrm{T} 3$ may related to bacteriocin producing bacteria that used as co-culture and also for bacteriocin that used as spray on the surface of the cheese after 3 days of brining, which may minimize the count of $P$. candidum.

Table 5. Effect of using bacteriocin producing bacteria and bacteriocin solution spray on counts of yeast and moulds.

\begin{tabular}{lllll}
\hline \multirow{2}{*}{ Age (day) } & \multicolumn{4}{l}{ Log cfu/gm } \\
\cline { 2 - 5 } & \multicolumn{4}{l}{ Camembert cheese treatments } \\
\cline { 2 - 5 } & T1 & T2 & T3 & T4 \\
\hline 20 day (After brining) & 8.88 & 8.25 & 7.49 & 8.55 \\
40 day (After brining) & 8.39 & 7.16 & 6.76 & 7.73 \\
\hline
\end{tabular}

T1: Camembert cheese with traditional method (control), T2: Camembert cheese made with bacteriocin producer isolate LAB 100, T3: Camembert cheese made with both LAB100 and further sprayed with PPBLS after 3 days of brining, T4: Camembert cheese made with both LAB100 and further sprayed with PPBLS after 10 days of brining.

\section{Conclusion}

From this study, it could be concluded that the overripening of Camembert cheese made with bacteriocin producing lactic acid bacteria (LAB100) added as adjunct coculture and sprayed with the partial purified bacteriocin; was controlled by minimizing the growth of $P$. candidum. As the rate of proteolysis indicated by Urea-PAGE was decreased, $\mathrm{pH}$ values, WSN/TN\% were decreased and the shelf life was extended; consequently, the taste, texture of Camembert cheeses was improved and no off-flavour was noticed comparing to control. Isolate LAB100 was phenotypically and genotypically characterized as newly lactic acid bacterial species of the genus of Lactobacillus.

\section{References}

[1] M. J. Sousa, P. L. H. McSweeney. Studies on the ripening of Cooleeney, and Irish farmhouse Camembert cheese, Irish Journal of Agricultural and Food Research. 2001, 40, 83-05.

[2] C. J. Coker, R. A. Crawford, K. A. Johanston, H. Singh, L. K. Creamer. Towards classification of cheese variety and maturity of the basis of statistical analysis of proteolysis dataa review. 2005, International Dairy Journal, 15: 631-643.

[3] McSweeney, P. H. (2004). Biochemistry of Cheese Ripening. International Journal of Dairy Technology, 57 (2/3): 127-144.

[4] M. B. Shaw. Modern cheese making: soft cheese, in: Modern Dairy Technology. Advances in Milk Products. Vol. 2, $2^{\text {nd }}$ edn., R. K. Robinson, ed., Elsevier Applied Science Publishing, London. 1993, pp 221-281.

[5] S. Swan, 2011. Methods to control the manufacture of soft mould ripened cheese. M. Sc, Thesis, Food Technology, Massey University.

[6] K. D. Antoniou, D. Petridis, S. Raphaelides, Z. Ben Omar, R. Kesteloot. Textural assessment of French cheese. Journal of Food Science. 2000, 65 (1): 168-172.

[7] P. F. Fox, T. P. Guinee, T. M. Cogan, P. L. H. McSweeney. Fundamentals of cheese science. 2000, Aspen Publications, Inc. United States of America.

[8] M. J. Sousa, Y. Ardo, P. L. H. McSweeney. Advances in the study of proteolysis during cheese ripening. International Dairy Journal. 2001a, 11: 327-345.

[9] M. J. Sousa, Y. Ardo, P. L. H. McSweeney. Studies on the ripening of cooleeney and Irish farmhouse camembert-type cheese. Irish Journal of Agricultural and Food Research, 2001b, 40, 83-95.

[10] P. Kolakowski, A. Reps, A. Babuchowski. Characteristics of pressurized ripened cheese. Polish Journal of Food and Nutrition Sciences. 1998, 7/48 (3), 473-482.

[11] S. Desorby, J. Hardy. Camembert cheese water loss through absorbent packaging, Journal of Food Science. 1994, 59 (5) 986-989.

[12] B. Roger, S. Desorby, J. Hardy. Respiration of Penicillium camemberti during ripening and cold storage of semi-soft cheese. 1998, Le Lait, 78, 241-250.

[13] S. Westall, O. Filtenborg. Spoilage yeasts of decorated soft cheese packed in modified atmosphere. Food Microbiology. $1998,15,243-249$.

[14] S. J. Walker, G. Betts. Chilled food microbiology. In: Stringer, M., Dennis, C. (Ed.). Chilled foods; a comprehensive guide: $2^{\text {nd }}$ edn. Woohhead Publishing Limited. England. 2000, Pp: 153.

[15] W. H. Holzapfel, P. Haberer, R. Geisen, J. Björkroth, U. Schillinger. Taxonomy and important features of probiotic microorganisms in food nutrition. Am. J. Clin. Nutr. 2001, 73, 365S-373S.

[16] H. Khan, S. Flint, PL. Yu. Enterocins in food preservation. Int J Food Microbiol. 2010, 141: 1-10. 
[17] P. D. Cotter, C. Hill, R. P. Ross. Bacteriocins: developing innate immunity for food. Nat. Rev. Microbiol. 2005, 3, 777788 .

[18] P. D. Cotter, R. P. Ross, C. Hill. Bacteriocins - aviable alternative to antibiotics? Nat. Rev. Microbiol. 2013, 11, 95-105.

[19] L. Deegan, P. Cotter, C. Hill, P. Ross. Bacteriocins: Biological tools for bio-preservation and shelf-life extension. International Dairy Journal. 2006, 16: 1058-1071.

[20] L. O'Sullivan, R. P. Ross, C. Hill. Review: Potential of bacteriocin-producing lactic acid bacteria for improvements in food safety and quality. Biochimie. 2002, 84, 593-604.

[21] S. C. Yang, C. H. Lin, C. T. Sung, J. Y. Fang. Antibacterial activities of bacteriocins: application in foods and pharmaceuticals. Frontiers in Microbiology. 2014, 5: 1-10.

[22] J. De Man, M. Rogosa, E. Sharpe (1960). A medium for the cultivation of lactobacilli. J. Appl. Bacteriol. 23, 130-135.

[23] J. G. Holt, N. R. Krieg, P. H. A. Sneath, J. T. Staley, S. T. Williams. 1994, Bergey's Manual of Determinative Bacteriology. $9^{\text {th }}$ edn. Williams and Wilkins.

[24] K. Elbanna, G. Hassan, M. Khider, R. Mandour. Safe Biodegradation of Textile Azo Dyes by Newly Isolated Lactic Acid Bacteria and Detection of Plasmids Associated With Degradation. J Bioremed and Biodeg. 2010, 1: 1-6.

[25] R. D. Page. Tree View: An application to display phylogenetic trees on personal computers, Comput. Appl. Biosci. 1996, 12: 357-358.

[26] O. H. Lowry, N. J. Rosenbrough, A. I. Farr R. J. Randall. Protein measurement with the folin-phenol reagent. J. Biol. Chem. 1951, 193: 265-271.

[27] J. Galloway. Production of soft cheese. Journal of the Society of Dairy Technology. 1995, 48, 36-43.

[28] SPSS. Statistical Package for Social Sciences. SPSS Inc., 1999, 444, North Michigen Avenue, Chicago, IL 606 11, USA.

[29] D. B. Duncan. Multiple range and Multiple F test. Biometr. 1955, 11: 142 .

[30] A. T. Andrews. Proteinases in normal bovine milk and their action on caseins. J Dairy Res. 1983, 50, 45-55.

[31] R. W. Blaksley, J. A. Boezi. A new staining technique for proteins in polyacrylamide gels using Coomassie Brilliant Blue G250. Anal. Biochem. 1997, 82, 580-582.

[32] AOAC. 2000. Official Methods of Analysis of AOAC International, $17^{\text {th }}$ edn., AOAC International, Gaitherburg, MD, USA, Official Methods 920.124, 926.08, 995.30, 20001.14. Washington, DC, USA.
[33] P Peláez, M Fresno, C Días and J Darias. Caracterización físico-química de quesos frescos elaborados con leche de cabra en la isla de Tenerife. Ciencia y Tecnología Alimentaria, 2003, 4 (2): 103-108.

[34] T. R. Marshall. Standard methods for the examination of dairy products, $16^{\text {th }}$ edn. American Public Health Association, Washington, U. S. A, 1992, pp 433-531.

[35] S. R. Tatini and K. L. Kauppi. Encyclopedia of Dairy Sciences. In: Roginski H, Fuquay JW and Fox PF (eds.) Vol. 1. Academic Press and Elsevier Science, Amsterdam, Boston, London, New York, Oxford, Paris, San Diego, San Francisco, Singapore, Sydney, Tokyo. 2003, pp. 74-79.

[36] G. Klein, A. Pack, C. Bonaparte, G. Reuter Taxonomy and physiology of probiotic lactic acid bacteria. International Journal Food Microbiology. 1998, 41: 103- 125.

[37] R. R. Colwell, R. A. Clayton, B. A. Ortiz-Conde, D. Jacobs, E. Russek-Cohen. The microbial species concept and biodiversity. In: Microbial Diversity and Ecosystem Function, eds Allsopp, D., Colwell, R. and Hawksworth, L. 1995, pp. 315. Wallingford, UK.

[38] L. De Vuyst, E. J Vandamme. Nisin, a lantibiotic produced by Lactococcus lactis subsp. lactis: Properties, biosynthesis, fermentation and applications. 1994, In Bacteriocins of Lactic acid bacteria. Eds De Vuyst, L., E. J. Vandamme. Blackie Academic \& Professional, Chapman \& Hall. London, Great Britain.

[39] P. Lavermicocca, F. Valerio, A. Evidente, S. Lazzaroni, A. Corsetti, M. Gobbetti. Purification and characterization of novel antifungal compounds from the sourdough Lactobacillus plantarumstrain 21B. Appl. Environ. Microbiol. 2000, 66: 4084-4090.

[40] J. Schnürer, M. J. Agnusson. Antifungal lactic acid bacteria as biopreservatives. Trends Food Sci. Technol. 2005, 16: 70 - 78.

[41] M. Dalmau, E. Maier, N. Mulet, M. Viñas, R. Benz. 2002, Bacterial membrane injuries induced by lactacin $\mathrm{F}$ and nisin. Int. Microbiol. 5: 73-80.

[42] T. J. Montville, K. Winkowski, R. D. Ludescher. Models and mechanisms for bacteriocin action and application. Inter. Dairy Journal. 1995, 5: 797-814.

[43] F. C. Odds, A. J. P. Brown, Gow, N. A. R. Antifungal agents: mechanisms of action. Trends in Microbiology. 2003, 11, 272279 .

[44] M. Khider. 1995, Proteolysis in Camembert cheese. M. Sc. Thesis, Department of Food Chemistry, University College Cork, Ireland.

[45] K. Katoka, K. Nukada, T. Miyamoto, T. Nakae. Changes in hardness and protein degradation during camembert cheese ripening. Jap. J. Zootech. Sci. 1987, 58, 356-358; cited from Dairy Sci., Abstr., 1988, 50, no. 1545. 